\title{
The risk of overvaluing networking on small and medium enterprises performance in Gauteng province, South Africa
}

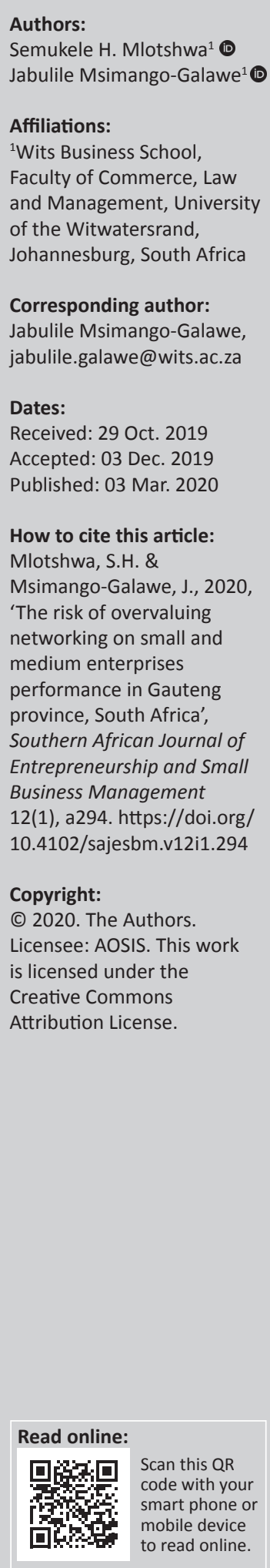

Background: Several studies have been conducted to investigate the relationship between networking and performance, but unfortunately findings have been inconclusive. Nevertheless, networking has been recognised as a vital element for enhancing competitiveness amongst small and medium enterprises (SMEs).

Aim: The objective of this study was to investigate the influence of different forms of networking, networking activities and the perceived importance of networking on SME performance.

Setting: The study was conducted in South Africa, more specifically on entrepreneurs who have SMEs operating in the Gauteng province.

Methods: This was a quantitative study with a cross-sectional research design on a sample size of 304. Multiple linear regression was employed as the core statistical technique to analyse the primary data.

Results: It was evident that the more value entrepreneurs put on networking, the lesser their businesses performed, as the relationship became negative. However, the more they got involved in networking activities and maintained the relationships, the better their businesses performed. It was interesting to note that social, business and managerial network forms emerged as one form of networking, which we have named business networking. However, the importance and maintenance of networks were very distinct as networks were valued higher than what we saw from the maintenance and participation in networking.

Conclusion: The study does not suggest that networking is irrelevant. However, it argues that this might be reflecting the risk of overvaluing networks. It is evident that networking influences performance of SMEs irrespective of whether it is social, business or managerial.

Keywords: social capital; social networks; business networks; managerial networks; SME performance.

\section{Introduction}

In developing countries, small and medium enterprises (SMEs) have become vital as they have the potential to improve income distribution, create new employment, reduce poverty and facilitate economic growth. As such, SMEs are seen as fostering the development of entrepreneurship, industry and the rural economy (Aremu \& Adeyemi 2011; Coulibaly, Erbao \& Mekongcho 2018; Love \& Roper 2015; Obeng, Robson \& Haugh 2014). However, these SMEs still face a multitude of challenges, and networking is deemed as one of the tools to assist them in facing these challenges (Coulibaly et al. 2018).

Due to these challenges, SMEs have to rely heavily on external support and resources to thrive, and these include external organisations, financial institutions, government, suppliers, relatives and many more. As a result, if an organisation can network with its suppliers, buyers and competitors, it will become a crucial ingredient to manage competition and achieve an advantage. Through networks and relationships, companies can identify their opportunities and try to avoid competition amongst them. However, the problem is that most SME owners do not measure the value of their networks or even view it as an essential part of their business growth (Anwar \& Ali Shah 2018; Johnson, Scholes \& Whittington 2005; Munyanyi \& Pooe 2019, O’Toole \& McGrath 2018).

According to Luo (2003) and Franco (2018), networks are regarded as a means of providing a diversity of knowledge, accessing resources, information and complementary assets for 
SME growth. Also, firms that emphasise building business networks increase flexibility, efficiency and competitive advantage. In a developing economic context such as South Africa, with one of its primary goals being firm growth, firms can effectively use network relationships to gain this competitive advantage that has been cited by many scholars (Franco 2018; Pratono 2018; Urban \& Sefalafala 2015; Wang, Chen \& Fang 2018).

Empirical studies on social capital and entrepreneurship have pointed out the benefits of networks on firm entrepreneurial performance and success. Furthermore, these scholars have shown that firms with networks comprising membership in professional associations and industry are likely to show growth (Kwon \& Arenius 2010; Krebs 2008; Schoonjans et al. 2013; Venter et al. 2015).

The objective of this study was to investigate the influence of different forms of networking (business, social and managerial) on business performance of SMEs in Gauteng province, South Africa, to ascertain which of the three influences SME performance the most, and further to understand the level of performance of those SMEs whose owners view networking as important and engage in networking activities

The objective of this study is attained by answering the following questions: 'to what extent do entrepreneurs value or view networking as important?', 'how involved are they in networking activities?', 'which form of networking do they engage in?' and 'to what extent does it influence the performance of their SMEs?'.

This study contributes to the social capital literature, especially the literature on the networking of SMEs in an emerging economy by giving a better understanding of which networking forms influence SME performance the most and also the effect of managing networks and perceiving them as important for business success.

The research findings of this study will guide entrepreneurs regarding networking forms and the value of each of them. Therefore, the results of this study provide evidence on whether SMEs' involvement in networking improves their performance, and contribute to the literature that is currently showing mixed results.

\section{Literature review}

Seed Academy (2017) found that the lack of business support including poor planning, lack of access to markets, lack of operational experience and poor financial management were the main contributors to business failure amongst South African small enterprises. Furthermore, small enterprises are challenged by limited access to resources and information that could lead to the identification of new opportunities or access to new markets (Grobbelaar, Gwynne-Evans \& Brent 2016; Herrington, Kew \& Mwanga 2017; Simsek \& Heavey 2011; Wiklund \& Shepherd 2005).
One prominent factor that can enhance the profitability of an SME, and thus lead to high performance and survival, is networking. Networking is defined as an enterprise, or its employees and owners, linking with other individuals or enterprises, which are not under their direct control in a costeffective way, by sharing contacts, information and exchanging resources with those enterprises (Anwar, Rehman \& Shah 2018; Franco 2018; Li \& Zhang 2007; Porter 1989).

The empirical literature on the impact of networking on the performance of SMEs has produced mixed results. Thrikawala (2011) finds a significant positive relationship between an SME's engagement in various networks and the performance of the SME. Similarly, Watson (2007) also finds that SMEs that are involved in networking have higher performance and survive longer. On the other hand, Rowley, Behrens and Krackhardt (2000) find a negative association between networking and performance.

Networking contributes to the growth of businesses by providing new ideas, practical assistance and emotional support (Anwar \& Ali Shah 2018; Hassan et al. 2018). Coulthard and Loos (2007) elaborate on networking in SMEs as an activity in which small businesses build and manage personal relationships with different individuals in their environment. Watson (2007) adds that the networks SMEs form with other businesses not only have the ability to influence their delivery and production of products or services but also help these small firms achieve economies of scale.

Networking allows small firms to obtain the necessary support from key stakeholders who are essential for the firm's growth (Huggins 2018; Le \& Nguyen 2009). Watson (2012) describes the importance of networks in assisting entrepreneurs in developing and accessing valuable ideas, resources and opportunities that are otherwise unavailable or difficult to obtain. It is through networking that SMEs can utilise their full potential to improve their performance (Anwar \& Ali Shah 2018; Krebs 2008; Valkokari \& Helander 2007).

It is crucial for entrepreneurs to actively participate in networks, as it will help them to improve their growth, success and performance.

In South Africa, it has been noted that SMEs contribute to the economy, although they do not grow as expected, but rather assume a survivalist position (Smit \& Watkins 2012). Garwe and Fatoki (2012) support this finding, arguing that small businesses in South Africa are mostly dominated by firms that only achieve a survival position and grow in number but not in size. They further add that in South Africa, the predominance of newly established SMEs does not advance from the initial stage of growth to other stages like success, take-off and maturity. Olawale and Garwe (2010) observed that approximately $75 \%$ of new SMEs in South Africa do not grow and develop into established businesses, and this agrees with recent reports (Herrington et al. 2017; Seed Academy 2017). 
The concept of networking remains relevant; this is because Håkansson and Snehota's No Business is an Island from 2017 (Ford \& Mouzas 2013) means that businesses should not exist in isolation but interact with other stakeholders. The conceptualisation of this study locates itself within the social network theory (SNT), as explained below.

\section{Social network theory}

Social network theory contrasts with the type of sociological theory that defines society as a built-up of individuals. It starts instead from the relations between individuals, and models society as constituted of networks made up of sets of relations or ties between the nodes (Wasserman \& Faust 1994).

Echoing SNT, Coleman and Coleman (1994) identified social capital as something inherent in the structure of relations between actors. Social capital is considered as a contract between individuals unconstrained by underlying economic arrangements. Actors are free to choose whether to build networks to further their self-interests. The critical component in building networks and, hence, creating social capital is a trust that the others will reciprocate their actions and will feel some obligations to do so (Coleman \& Coleman 1994).

Research suggests that networks are a crucial aspect of entrepreneurial success. Studies indicate that networking allows entrepreneurs to enrich their knowledge of opportunities, gain access to critical resources and deal with business obstacles (McFarlin, Coster \& Mogale-Pretorius 1999). Networking is also referred to as entrepreneurs' social capital base, and social capital is crucial to entrepreneurs and is critical for business growth (Low \& MacMillan 1988).

The premise behind the notion of social capital is rather simple and straightforward - investment in social relations with expected returns. This definition is consistent with various scholars (Burt 2009; Coleman \& Coleman 1994; Portes 1998). Entrepreneurs engage in interactions and networking in order to produce profits.

Social capital is considered to be the foundational theoretical perspective in entrepreneurship (Taylor \& Murphy 2004). It is a key outcome of networking, a crucial micro-foundation of entrepreneurial action (Adler \& Kwon 2002). Social capital helps entrepreneurs, especially in capitalising on market opportunities, identifying, collecting and allocating scarce resources, gathering information, influence and sponsorship, improving outcomes in turbulent times, providing legitimacy, preventing failure and strengthening the innovative flexibility and competitiveness of SMEs (Gedajlovic et al. 2013). The key insight from the literature is that social capital is a central determinant of entrepreneurial outcomes.

The SNT argues that individuals interact in different social interactions, which eventually result in the formation of networks. Networks are created as a result of these interactions. The ties or relationships amongst actors (Hazzard-Robinson 2012) can result from a conversation, affection, friendship, kinship, economic exchange, information exchange or other forms of social interaction. Furthermore, the SNT argues that the value individuals receive when they are involved in a highly fragmented network is very low. Therefore, individual actors seek to increase the value they receive by creating a more integrated network, as networks help the actors exchange beneficial information and resources (Machirori \& Fatoki 2013).

The logic of understanding the social network approach, about SMEs, begins at the point where the business owner interacts with other individuals to establish a transaction or a relation. Business owners are in constant social interaction with individuals and other businesses. The interactions end up creating a relationship which is very important for business owners (Steier \& Greenwood 2000). Hence, SNT is very important for understanding the influence which the social relations of business have on the outcome of the business (Jones, Hesterly \& Borgatti 1997).

This study argues that the readily available information entrepreneurs get through their social capital reduces uncertainties and thereby makes individuals more assured to become entrepreneurs. Social capital in SMEs with networks that facilitate the discovery of opportunities, along with identification, collection and allocation of scarce resources, provides resources and support required for entrepreneurship, reduces transaction costs by allowing the co-ordination of activities and also helps in collective decision-making (Davidsson \& Honig 2003).

\section{Forms of networks and networking}

There are different forms of networking, which includes social, business, financial, political and managerial networking (Anwar \& Ali Shah 2018). However, in this study, we focus only on three, that is, social, managerial and business networking. This study argues that the difference between the three forms of networks lies in the types of actors or individuals involved and the ties between the actors. Although this study acknowledges that there are similarities and overlaps between these three forms, it is still worth conceptualising and researching them individually. Social networks in the past tended to have stronger social ties, with family, friends and relatives, although these days because of social media, relationships from those platforms, seemingly weaker ties, are still beneficial as well. The business network involves more formal relationships with everyone in the business, including customers, suppliers and other relevant stakeholders. Lastly, managerial networks involve management relationships on a more formal basis with managers from two or more businesses. However, all forms are expected to directly or indirectly benefit the business and give it a competitive advantage (Anwar \& Ali Shah 2018; Anwar et al. 2018; Ford \& Mouzas 2013; Su et al. 2011). Drawing from the SNT, it can be suggested that successful business ownership depends on the ability of owners to gain access to resources (social, managerial and business) not under their control in a cost-effective way through networking 
(Watson 2007). Different stages of business development and growth require different approaches to networking (Chung 2012). We will now discuss the influence of the different networking forms on SME performance.

\section{Social networking and small and medium enterprises performance}

Hung (2006) defined social networks as linkages or social systems of the individual(s) that facilitate access to resources or valued sources of information that are beneficial to business enterprises. Lea et al. (2006) considered social networks as sets of people who are connected by socially meaningful relationships, such as friendship, co-working and information exchange, to achieve mutual goals.

Family and friends are characterised as strong ties. These are persons with whom the entrepreneurs share a close emotional relationship. Weak ties are characterised as low-trust relations. Weak ties do not have the intimacy or the emotionality of strong ties. Social networks, in this study, include relationships which an individual has with family members, relatives, friends, as well as ties with social associations and clubs. The contribution of social networks for businesses is amongst the most important discoveries in business research (Gold \& Light 2000). Social networks are assumed as vital structures in which economic transactions are embedded.

Krebs (2008) posits that the essence of social capital entails that it is not what individuals can do that provides a competitive advantage. This view ties in with Labianca and Brass (2006) who argued that in business enterprises, employees' and managers' social contacts convey benefits that create opportunities for their enterprises, which lead to competitive advantages. Based on the literature reviewed, the following hypothesis was formulated:

H1: Social networking positively influences SME performance.

\section{Business networking and small and medium enterprises performance}

Labianca and Brass (2006) define business networks as voluntary inter-business co-operation between at least three enterprises whose entrepreneurial autonomy is partially limited by their co-operation. $\mathrm{Xu}$, Lin and Lin (2008) view business networks as a set of two or more connected relationships in which each exchange relation is between business enterprises that are regarded as collective actors in the network. Besser, Miler and Perkins (2006) describe business networks as formal linkages composed primarily of business owners or managers established to facilitate the success of their respective enterprises.

According to Li and Ferreira (2006), business networks are linkages, whether formal or informal, which facilitate the exchange of resources. Besser et al. (2006) define business networks as formal relationships that are created by business owners or managers to help to facilitate the success of their business. In the context of this research, business networks refer to networks which SMEs have with governmental or non-governmental organisations and with business consulting firms that assist them (Ford \& Mouzas 2013; Huggins 2018).

Business networks can have an impact on the performance of a business. This understanding is supported by Chittithaworn et al. (2011), who pointed out that business networks play an important role in helping businesses gain organisational legitimacy and build a good reputation. The relationships formed in business networks create an opportunity where a business can access information about industry trends and future business opportunities (Cooney \& Flynn 2008). In emerging economies, the market is profoundly affected by a government-led redistributive mechanism, implying that officials influence business practices ( Hubert, Elgar \& Rainer 2001; Li \& Zhang 2007). Thus, the following hypothesis is formulated:

H2: Business networking positively influences SME performance.

\section{Managerial networking and small and medium enterprises performance}

Managerial networks involve networking with suppliers, customers and similar enterprises. Managerial networks involve links between the manager of a firm and the managers of other firms. Managerial networking between managers from two firms presents opportunities for information acquisition and is essential. These managerial ties have pivotal influences on firm activities, provide a source of competitive advantages, enable the superior performance of the firm and help in increasing the legitimacy of firms (Le \& Nguyen 2009).

Kumar Panda (2014:5) describes managerial networks as the 'structure in which top managers of firms connect with others who are directly or indirectly connected with the organisations'. Le and Nguyen (2009) emphasise that managerial networks are relations with suppliers, customers and other businesses that enhance the legitimacy of the business. According to $\mathrm{Li}$ (2005), managerial networks require a tie between the managers of a business and other managers of another business. Also, managerial networks help business owners learn appropriate business behaviour (Heshmati 2013). Peng and Luo (2000) state that managerial ties have two aspects that are business and political; however, in this study, we do not divide it into two aspects (Chung 2012) but investigate it as a single construct. As a result of the benefits and competitiveness that are gained from networking, this study hypothesises the following:

H3: Managerial networking positively influences SME performance.

\section{Small and medium enterprises performance}

A review of the literature yielded a prolific amount of research about performance measurements. The construct of firm performance has captured the interest of scholars over the past decades. Performance refers to the SME rather than the individual entrepreneur. This is sometimes referred to as organisational performance in the literature. The concept of organisational performance has been studied in detail in 
strategic management research, with great focus being placed on determining the right measures of firm performance (Kumar Panda 2014; Shava \& Rungani 2016; Steigenberger 2014).

The measures of performance include sales level, sales growth rate, cash flow, return on shareholder equity, gross profit margin, net profit from operations, profit to sale ratio, return on investment and ability to fund business growth from profits, which were used as indicators of performance; these are subjective indicators (Cooper \& Nakanishi 2010, Shava \& Rungani 2016, Fatoki 2011) of which some are adopted for this study.

\section{Financial (objective) measures}

Financial measures of performance can be referred to as the results of a firm's operations in monetary terms. According to Kellen and Wolf (2003), financial measures of performance are derived from the accounts of a firm or can be found in the firm's profit and loss statement or the balance sheet. The financial measures are also referred to as objective measures because they can be individually measured and verified (Pratono 2018; Rosenbusch et al. 2013).

Sales growth: This refers to an increase in sales over a specific period, usually, but not always, annually.

Delmar Davidsson and Gartner (2003) suggest that if there is one measure of SME performance that could be used, it should be sales growth (Baum, Locke \& Smith 2001; West \& Noel 2009).

Return on Equity (ROE): As suggested by Watson (2007), ROE should be the starting point for any systematic analysis of firm performance. Return on equity relates the earnings left over for equity investors after debt service costs have been factored into the equity invested in the firm.

Return on Assets (ROA): Cook and Uchida (2004) suggest that ROA is used as a vital measure of profitability. It provides information about how much profit is generated, on average, by each unit of the assets of the firm (Petersen \& Schoeman 2008).

Schayek \& Dvir (2011) states that SME owners and managers are very sensitive about disclosing or discussing their information relating to their firm's financial performance. According to Watson (2007), SMEs are not required or regulated to report and publish their financial records; it is difficult to obtain, directly, the financial figures on sales and profitability of most SMEs. This problem may be more prevalent in developing countries, where despite the high failure rate of SMEs, limited follow-up is conducted on how they perform annually. Therefore, most research studies, such as Leech, Barrett and Morgan (2014), Watson (2007) and Msimango-Galawe and Urban (2019), have made use of a Likert scale which measures sales growth and profitability growth as financial performance measures. These are deemed as subjective measures, and a similar technique is used by
Thrikawala (2011) and Watson (2012). This approach is implemented as it avoids the direct approach of asking for sales or profitability figures but infers the performance, indirectly, through the responses on the level of satisfaction with sales and profitability growth of the firm.

\section{Non-financial (subjective) measures}

The non-financial measures are also known as the subjective performance measures. Using the subjective performance measures, Likert scaling questions are used to measure firm performance from the top management perspectives as cited by Selvarajan et al. (2007) in Marimuthu, Arokiasamy and Ismail (2009). The use of non-financial measures of performance supplements accounting measures and gives data on progress relative to customer requirements or competitors and other non-financial objectives that may be important in achieving profitability. Also, non-financial measures can provide indirect, quantitative indicators of a firm's intangible assets, such as intellectual capital and customer satisfaction and loyalty, which are drivers of success.

In measuring SME performance, no one measure of performance should be taken on its own and to obtain an accurate measure of how a firm is performing, different measures should be used together. Marimuthu et al. (2009) used a combination of both financial and non-financial performance measures, utilising sales growth and employment growth as the measures of performance. Schayek \& Dvir (2011) utilised a Likert scale measuring satisfaction with sales growth and profitability growth as the primary measures of financial performance.

Fatoki (2011) utilised satisfaction with overall performance and satisfaction with performance compared to competitors as the measures of non-financial performance. Schayek \& Dvir (2011) stated that measuring both financial and non-financial performance through indirect questions on sales growth, profitability and overall satisfaction improves the response rates of SMEs. It also enables an objective measure of SME performance, and the same approach is applied in this study.

\section{Performance based on value creation}

In more recent years, scholars have applied a resource-based view to conceptualising performance. From this perspective, an organisation has unique resources that are difficult to imitate or substitute. These resources can be used to create a competitive advantage which can be leveraged to create value (monetary and non-monetary), and such value can be distributed to the organisation' stakeholders, depending on their bargaining power (Steigenberger 2014). As much as value creation can be both monetary and non-monetary depending on whom it is created for, this study focuses mainly on monetary value creation which relates to SME performance. The stakeholders' appropriation of the value created is the subject of appropriation theory (Coff 1999). Measures of financial performance, such as ROA and ROE, actually measure the value appropriated by shareholders; they do not measure the value created by the organisation. 
Miller, Washburn and Glick (2013) argue that performance measures should be selected based on what is of interest to a specific stakeholder group. For this research, 'performance' is evaluated from a shareholder and customer's perspective. Profitability, growth and market value are of key interest to shareholders. On that basis, profitability and market value are excluded as measures of performance. Growth refers to the net change in a specific variable within a specific period, given a certain context (Cooper \& Nakanishi 2010). Growth can be applied as a subjective measure by evaluating the perception of a change in a specific variable in a fixed period.

\section{Research methods and design}

The research design was cross-sectional, which adopted a positivist paradigm. This paradigm uses a deductive approach where theories are tested, and hypotheses are generated (Cooper \& Schindler 2014), which is the case in this study.

\section{Study population and sampling strategy}

The study population comprised SMEs that operate across various sectors in Gauteng province. A simple random sampling was employed to collect primary data using selfadministered surveys, and the sample size was 304. All questionnaires were completed manually and 500 printed copies of the questionnaire were distributed physically to several organisations with business owner membership, of which 311 were returned, providing a response rate of $62 \%$. Of the 311 that were returned only 304 were usable. There were a few disqualifying questions; the respondents had to own an SME in Gauteng, must have been operating for at least 12 months to be able to share performance figures, and the respondents should be owner-managers. These were questions at the beginning of the questionnaire to ensure that only the people who fall within the target group completed the survey. If they answered 'no' to any of the above, then they were excluded and if 'yes' they continued with the survey. Respondents were given 1 week to complete the survey, and after 2 weeks the researcher went back to collect the completed questionnaire.

\section{Sampling frame and unit of analysis}

Because of the practical implications of contacting SMEs across Gauteng, the sample was selected from SMEs that are associated with business groups which provide support to small businesses. Hence, the sampling frame included SME owners who operate across various sectors in Gauteng and are found within small business databases. The target respondent was the owner-manager who has the responsibility of dealing with the day-to-day running of the business within the enterprise. The sample frame was expanded to include Gauteng SMEs that were contactable through various business groups on social platforms.

\section{Research instrument and measurement scales}

The instrument was developed based on scales that were previously used in similar studies as using existing scales reduces the risk of low external validity (Cooper \& Schindler 2014). A seven-point Likert scale was used, with scores ranging from 1 to 7 where 1 denotes strongly disagree and 7 denotes strongly agree.

Independent variables: The independent variables were business, social and managerial networks where questions were asked about whether entrepreneurs maintain business relationships within such networks and as to how important they view such networks for their businesses.

Dependent variable: The dependent variable was performance, which asked questions about business growth and financial performance. The respondents were asked to rate how well their businesses are growing and how satisfied they are on financial performance. The measurements of the dependent variable were all subjective indicators.

\section{Data screening and analysis}

Data were collected through manual surveys, then captured in Microsoft Excel spread sheet and cleaned before importing into Statistical Package for the Social Sciences (SPSS) for statistical analysis. The screening included checking for missing values, outliers, unengaged respondents and reverse questions. Multiple linear regression was employed to test hypotheses on the three forms of networking and the performance of SMEs. Before employing regression, frequency tables and descriptive statistics were produced to summarise the demographic data and analyse the properties of the data set (Cooper \& Schindler 2014; Creswell 2014; Field 2016).

Furthermore, exploratory factor analysis (EFA), Cronbach's alpha and correlational analysis were conducted to test the validity, reliability of scales and relationships between variables, respectively. Principal axis factoring was used as the extraction method with Promax employed to optimise the results for ease of interpretation of the pattern matrix. Moreover, the scree plot in conjunction with Kaiser's criterion of eigenvalues of greater than 1 assisted the study to decide on the best number of factors to extract and retain (Cooper \& Schindler 2014; Drost 2011; Field 2016; Hair et al. 2010).

\section{Ethical consideration}

Ethical clearance was obtained from the Wits Business School of the University of the Witwatersrand with ethics clearance number assigned: WBS/EN1757662/677.

\section{Results}

Demographic data were collected, and it included gender, age and level of education. More than half of the respondents (54\%) were men and $46 \%$ were women. In the sample, $53 \%$ of the respondents were in 36-45 years age group, $28 \%$ were in 46-55 years age group and 20\% were in 18-35 years age group. The sample was made up of mostly individuals who had a tertiary qualification, with $40 \%$ having attained a diploma, 25\% having degrees and another 30\% having 
postgraduate degrees or diplomas. However, those with high school and no schooling were in the minority group (5\%).

Data on the business characteristics were collected, which included sector and age of the business. Most of the businesses were from the manufacturing (42\%), agriculture (30\%) and construction (19\%) sector, and the rest is distributed amongst other sectors. Lastly, regarding the age of the business, about $20 \%$ of the businesses had been in existence for 1-4 years, $47 \%$ for $5-9$ years, $22 \%$ for $10-14$ years, whilst another $11 \%$ had been in business for 15 years and above.

\section{Validity and reliability testing}

Before testing this study's hypotheses, EFA and reliability analysis (Cronbach's alpha) tests were conducted to test the construct validity and internal consistency of the scales, respectively. The primary goal of factor analysis is to determine the underlying structure amongst the variables in order to explain the pattern of inter-relations (correlations) amongst the variables as multi-item scales were used to collect data on each of the key constructs. Sets of variables that are highly inter-related are known as factors (Cooper \& Schindler 2014; Field 2016; Leech et al. 2014), and this helps reduce the dimensions of the variables.

Firstly, the study confirmed that no EFA assumptions were violated. The data matrix showed sufficient correlations $(r>0.3)$ to proceed with the application of factor analysis. Additionally, the Kaiser-Meyer-Olkin (KMO) measure of sampling adequacy was high $(\mathrm{KMO}=0.975>0.5, p<0.05)$, with the Bartlett's test of sphericity significant at greater than 1 (Drost 2011; Field 2016).

Table 1 shows that only three factors emerged from the EFA, and all three with valid and reliable scales. The three factors were named as follows: (1) Network_Maintain, which is a construct representing questions asked about having and maintaining business relationships; (2) Network_Importance which represents questions about the importance of having business relationships; and (3) performance which represents questions about growth and the level of satisfaction of financial performance of the SME.

According to the initial scales and literature, there were three forms of networks: business, social and managerial networks (Anwar \& Ali Shah 2018). However, this study findings produced a different outcome - all the three forms of networks converged into one factor, which this study labelled as business networks. As much as the three forms of networks converged, there was still divergence of the maintenance and importance constructs of these networks.

The validity and reliability of each of the factors were supported with statistics where Network_Maintan had 14 items at $(\alpha=0.994)$ and Network_Importance had 12 items at $(\alpha=0.974)$. These were excellent results as the Cronbach's alphas were all greater than 0.7 and had more than three
TABLE 1: Exploratory factor analysis and reliability results.

\begin{tabular}{|c|c|c|c|c|}
\hline Constructs & Items & Factor 1 & Factor 2 & Factor 3 \\
\hline \multirow{14}{*}{$\begin{array}{l}\text { 1. Networks } \\
\text { Importance } \dagger\end{array}$} & Business_NI1 & 0.962 & - & - \\
\hline & Business_NI2 & 0.951 & - & - \\
\hline & Business_NI3 & 0.953 & - & - \\
\hline & Business_NI4 & 0.943 & - & - \\
\hline & Business_NI5 & 0.940 & - & - \\
\hline & Business_NI6 & 0.967 & - & - \\
\hline & Business_NI7 & 0.960 & - & - \\
\hline & Business_NI8 & 0.975 & - & - \\
\hline & Social_NI1 & 0.922 & - & - \\
\hline & Social_NI2 & 0.939 & - & - \\
\hline & Social_NI3 & 0.934 & - & - \\
\hline & Managerial_NI1 & 0.948 & - & - \\
\hline & Managerial_NI2 & 0.944 & - & - \\
\hline & Managerial_NI3 & 0.920 & - & - \\
\hline \multirow{12}{*}{$\begin{array}{l}\text { 2. Networks } \\
\text { Maintain } \bar{t}\end{array}$} & Business_NH1 & - & 0.936 & - \\
\hline & Business_NH2 & - & 0.880 & - \\
\hline & Business_NH3 & - & 0.768 & - \\
\hline & Business_NH4 & - & 0.910 & - \\
\hline & Business_NH5 & - & 0.933 & - \\
\hline & Business_NH6 & - & 0.870 & - \\
\hline & Social_NM1 & - & 0.935 & - \\
\hline & Social_NM2 & - & 0.844 & - \\
\hline & Social_NM3 & - & 0.868 & - \\
\hline & Managerial_NM1 & - & 0.909 & - \\
\hline & Managerial_NM2 & - & 0.906 & - \\
\hline & Managerial_NM3 & - & 0.852 & - \\
\hline \multirow[t]{9}{*}{ 3. Performance $\S$} & Growth_R1 & - & - & 0.605 \\
\hline & Growth_R2 & - & - & 0.593 \\
\hline & Performance_S1 & - & - & 0.709 \\
\hline & Performance_S2 & - & - & 0.667 \\
\hline & Performance_S3 & - & - & 0.734 \\
\hline & Performance_S4 & - & - & 0.504 \\
\hline & Performance_S5 & - & - & 0.473 \\
\hline & Performance_S8 & - & - & 0.465 \\
\hline & Performance_s9 & - & - & 0.430 \\
\hline
\end{tabular}

Note: Extraction method: Principal axis factoring.

$\mathrm{NI}$, Network importance; R, Revenue; S, satisfaction levels.

$\dagger$, Cronbach alpha $=0.974$ (12 items); $\$$, Cronbach alpha $=0.994$ (14 items); $\S$, Cronbach alpha $=0.912$ (9 items).

items each (Field 2016). Similarly, the performance was measured with two subjective measures, which were growth as perceived by the entrepreneurs and their levels of satisfaction. Both these measures converged into one factor after removing Growth_R3, which was not loading onto any factor and Performance_S6 and S7, which loaded incorrectly. After removing the two items, the factor was labelled Performance with nine items at $(\alpha=0.912)$. The total variance explained by the items was $79 \%$, which is very good as it explained more than $60 \%$ of what is happening in the data set (Field 2013). All the analysis after EFA and the reliability tests focused on the three constructs of network maintenance, network importance and SME performance.

\section{Descriptive and correlational analysis}

The results in Table 2 reveal that Network_Importance was the highest rated construct (mean $=5.6227$ ), whilst Network_Maintain had a mean of 2.7919, which means that as much as entrepreneurs are low on maintaining business relationships on the networks they have, they deem 
TABLE 2: Descriptives and Pearson's correlation.

\begin{tabular}{llccccc}
\hline Number & Variables & Mean & SD & $\mathbf{1}$ & $\mathbf{2}$ & $\mathbf{3}$ \\
\hline 1 & Network_Maintain & 2.792 & 1.356 & 1 & - & - \\
2 & Network_Importance & 5.623 & 1.659 & $-0.577 *$ & 1 & - \\
3 & Business performance & 3.011 & 1.057 & $0.767 *$ & $-0.689 *$ & 1.000 \\
\hline
\end{tabular}

*, Correlation is significant at the 0.01 level (2-tailed).

networking and networks an important component of their business activities. This finding is somewhat unusual as conventional wisdom suggests that if one deems something so important, they are then expected to rank high on the level of networks they keep and maintain. The business performance although was somehow close to the neutral scale of 3 (mean $=3.011)$, it is somewhat not convincingly high. It will be interesting to see the relationships of these constructs as the literature suggests that there is some positive relationship between networking and SME performance.

\section{Correlations}

It is interesting to note that there is a negative relationship $(r=-0.577, p<0.01)$ between maintaining (Network_Maintain) business relationships and the perception on the importance (Network_Importance) of these same relationships or networks; this relationship is moderate and significant. Nevertheless, there were strong relationships between the independent variables (Network_Maintain $[r=0.767, p<0.01]$ and Network_Importance $[r=-0.689, p<0.01]$ ) and the dependent variable (SME performance).

Both relationships are significant although Network Maintain has a positive and Network_Importance has a negative relationship with SME performance.

Based on these correlational results, it was deemed viable to conduct further analysis and test the hypotheses on the influence of Network_Maintain and Network_Importance on SME performance.

\section{Hypotheses testing}

This study's objective was to test the influence of social, business and managerial networking on SME performance in order to see which one has the most influence. As a result, three hypotheses were formulated:

H1: Social networking positively influences SME performance.

H2: Business networking positively influences SME performance.

H3: Managerial networking positively influences SME performance.

These hypotheses were changed after the validity and reliability test, as the factor structure was different from what previous studies had found or suggested. Figure 1 presents both the original and the revised conceptual framework, which includes hypotheses 4 and 5 as new hypotheses developed as a result of the validity and reliability test findings.

The new hypotheses to be tested were:

H4: Maintaining networks positively influences SME performance.

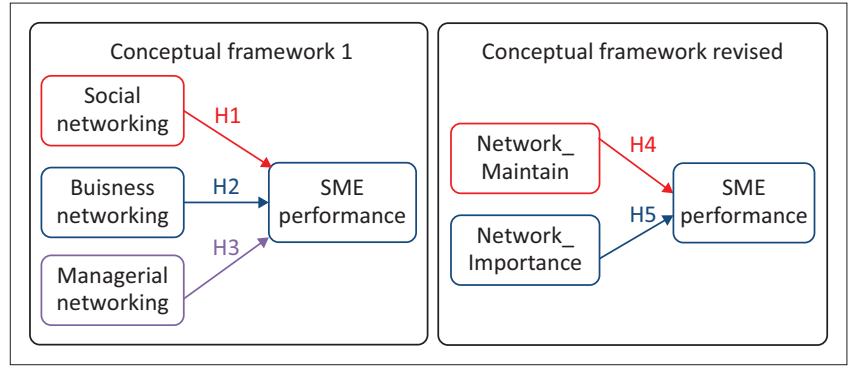

Source: Adapted from Hung, H., 2006, 'Formation and survival of new ventures: A path from interpersonal to interorganizational networks', International Small Business Journal 24(4), 359-378. https://doi.org/10.1177/0266242606065508; Möller, K., 2010, 'Relationships and networks', in M.J. Baker \& M. Saren (eds.), Marketing theory: A student text, pp. 304-329, Sage, London. https://doi.org/10.4135/9781446280096.n14 Thrikawala, S., 2011, 'Impact of Strategic Networks for the Success of SMEs in Sri Lanka', World Journal of Social Sciences 1(2), 108-119.

FIGURE 1: Revised conceptual framework.

H5: The level of importance (value) put on networking positively influences SME performance.

Furthermore, this enabled the study to determine whether entrepreneurs actively network, maintain business relationships and value networking as a tool for business success.

\section{Results from multiple regression analysis}

Table 3 shows that adjusted $R^{2}$, the coefficient of determination which is a measure of the predictive capacity of the model, has a value of 0.676 . This indicates that $67.6 \%$ (converted to a percentage for ease of interpretation as correlations go up to 1 and when interpreted as a percentage equated to $100 \%$ ) of the variance that is seen on business performance can be explained by Network_Maintain and Network_Importance, and this model is significant at $p<0.05$ according to the regression analysis results as presented in Table 3.

\section{Hypotheses 1-3}

No regression results as these three hypotheses were excluded from further analysis because the items did not converge into the three factors representing forms of networking as envisaged.

\section{Hypothesis 4}

Network_Maintain positively influences SME performance (supported - positive and significant): The results in Table 3 confirmed our hypothesis that Network_Maintain influences SME performance positively. Fifty-five per cent of the change in SME performance can be explained by the networks that the entrepreneur maintain, and this is significant at $\beta=0.554$ $(p<0.05)$.

\section{Hypothesis 5}

Network_Importance positively influences business performance (not supported - negative and significant): It is evident from Table 3 that Network_Importance negatively influences SME performance. Thirty-seven per cent change in SME performance can be explained by a change in the networks that the entrepreneurs perceive as important or deem valuable. The influence is significant at $\beta=-0.369$ $(p<0.05)$. It is suggested that the more an entrepreneur thinks 
TABLE 3: Multiple regression.

\begin{tabular}{lccccccc}
\hline Variables & Model & B & Beta & SE & $t$ & Sig. & 95\%Cl \\
\hline Constant & - & 3.129 & - & 0.209 & 14.960 & 0.000 & {$[2.717 ; 3.540]$} \\
Network_Maintain & - & 0.431 & 0.554 & 0.031 & 13.831 & 0.000 & {$[0.370 ; 0.493]$} \\
Network_Importance & - & -0.235 & -0.369 & 0.025 & -9.221 & 0.000 & {$[-0.285 ;-0.185]$} \\
F(2) & 317.518 & - & - & - & - & - & - \\
$R$ & 0.824 & - & - & - & - & - & - \\
$R$-Square & 0.678 & - & - & - & - & - & - \\
Adjusted $R$-Square & 0.676 & - & - & - & - & - & - \\
\hline
\end{tabular}

Note: Dependent variable: Business performance.

Significant at $p<0.05$

$B$, beta; SE, standard error; Sig., significance.

that networking is important, the less his or her SME performs. Therefore, this study does not argue that networking is not important, but rather that this might be reflecting the risks of putting too much value and reliance on networking whilst not engaging in networking activities enough.

The study performed some tests to ensure that regression analysis assumptions are not violated. Tests conducted included linearity, normality, multicollinearity and outliers. The results showed the collinearity statistics with The variance-inflation factor $(\mathrm{VIF})<10$ and $>1$ and $\mathrm{T}>0.2$, which suggest that there is no collinearity problem (Field 2013; Galawe 2017); multicollinearity is when two or more predictor variables in the model are highly correlated $(r>0.8$ or 0.9 ) and provide redundant information about the responses. The main reason for carrying the test was to determine if any of the independent variables are similar (Field 2016). Table 2 shows a correlation coefficient of the different variables, and none of them has a coefficient of $r>$ 0.8 ; therefore, there is no problem of multicollinearity, and moreover, no outliers were detected.

\section{Discussion}

The objective of this study was to investigate the influence of different forms of networking on the performance of SMEs. In this study, forms of networking included business, managerial and social networking. These two forms, however, emerged as one networking construct which we named business networking, and this changed the focus of the study from investigating three forms of networking to investigating the importance and maintenance of networks, and further to investigate which of the three influences SME performance the most and to understand the level of networking activities entrepreneurs engage in.

\section{The key findings}

As much as the findings confirmed the influence of networking on SME performance, the dimensionality suggested by literature (Anwar \& Ali Shah 2018) was not confirmed. Moreover, the importance and maintenance of networking correlated negatively and positively with SME performance, respectively.

However, networking was divided into the importance of networks and maintenance of networks. It was evident that although entrepreneurs are low on maintaining business relationships on the networks, they still deemed networking and networks an important component of their business activities. The mean score on SME performance and maintenance of networks was low (approximately 3 on a seven-point Likert scale) for both, which then supports the networking theories and literature that networking improves business performance; therefore, the lower the level of networking, the lower the performance of the SME (Chung 2012; Kumar Panda 2014; Pratono 2018).

The finding that was somewhat unusual was the finding on the negative relationship between the value put on networking and the level of networking entrepreneurs engaged in and maintained, as conventional wisdom suggests that if one deems something valuable in this case of networking, then they are expected to rank high on the level of networks they engage in and maintain. However, this was not the case in this study and even the negative relationship between Network_Importance and SME performance was not expected.

Although some scholars talk about possible negative relationship between networking and performance, it was not specifically on the perceived importance of networking and performance. However, it was in cases where there may be weak ties, where an entrepreneur has too high social network or where networking goes beyond a certain level resulting in the entrepreneur overly committed administratively and emotionally which is costly (Anwar \& Ali Shah 2018; Chen et al. 2007, Chen \& He 2011; Watson 2007). Investigating the influence of networking on SME performance is advocated as a meaningful pursuit; unfortunately, we were unable to get conclusive results on the relationship between the importance of networks and SME performance. The findings then call for further research using a mixed-method approach to delve into these somewhat surprising results.

The findings of the study are consistent with the findings of several studies on the maintenance of networks and SME performance (Anwar et al. 2018; Kumar Panda 2014; Pratono 2018; Sarens et al. 2015; Tendai 2013; Watson 2007). This implies that highly diverse networking offers a useful resource mix that, in turn, improves the business performance of SMEs. However, there are no studies to support the finding on the network importance and SME performance negative influence.

\section{Strengths and limitations}

In addressing the limitations of the current and similar research, it is concluded that most of the literature dealing with networking approaches the topic from a descriptive perspective. Such an approach causes variation in the conceptualisation of types of networking, such as social networking, managerial networking and business networking. These differences create confusion and make respondents interpret networking as one type; in this study, 
the respondents managed to differentiate the importance and the maintenance element of the questions. By investigating the types of networking, Jack, Dodd and Anderson (2008) demonstrated that networks are vital living organisms, changing, growing and developing over time.

This study looked at demographics but did not look at how they influence SME networking and performance. However, other factors influence the networking of SMEs, such as efficiency, political influence, market strategy, internalisation, personal characteristics and firm characteristics. In this regard, future research should incorporate other factors in order to have a better understanding of the factors influencing networking, such as employee working experience, international networking and ethnic networking.

This study suggested various factors that influence initiating networking activities amongst SMEs. As networking is an important topic to study, studying the factors will help SMEs get involved in networking activities; therefore, the knowledge of the factors is important for future research.

\section{Implications and recommendations}

This study has practical implications for the big corporations, organisations, insurance companies, as well as industry regulators, government, interested stakeholders, business associations and suppliers, who desire to promote networking in South Africa, especially for SMEs through enterprise development programmes.

According to Tendai (2013), networking enables SMEs to engage in collective bargaining with suppliers and enjoy large discounts of bulk purchasing from suppliers, which increases the access to trade credit by SMEs.

Therefore, entrepreneurs are encouraged to network to share ideas, knowledge and resources because networking opens channels and enables owners to interact and have relationships with influential people who positively contribute to the enterprises. However, at the same time, entrepreneurs are warned not to overvalue this.

Both literature and the findings of this study show that networking is one of the factors that can contribute to the success every entrepreneur craves in business (Anwar et al. 2018; Anwar \& Ali Shah 2018; Fatoki 2011; Huggins 2018). Owners of businesses should be involved in business networking and managerial networking, which will enhance their businesses. It can be concluded that networking has become a viable tool in the hands of any entrepreneur for business differentiation and success because the business world is becoming more competitive in the emerging global village. Based on the findings of this study, some recommendations and suggestions are meaningful, which may help and ensure the impact of networking on SME performance.

It should be noted that this study has made contributions in understanding different forms of networking, the importance of networking, networking maintenance and the influence it has on the performance of SMEs.

However, there are some limitations which lay the foundation for future research. The data for this study were only collected from the Gauteng province of South Africa, which is known as the economic hub of South Africa; therefore, future research should broaden the scope to include all provinces of the country. Furthermore, it is recommended that a qualitative element with a small sample of the study's SMEs in Gauteng should be included in order to gain more in-depth knowledge as to why some of the quantitative findings are contradictory to the literature.

Accordingly, the applicability of the findings to other provinces is not known. Therefore, future research should include all provinces to get a larger sample in order to ascertain if the findings could apply to the broader population of SMEs in the country. Furthermore, future research should investigate the different forms of networking, whether the forms exist in its present state in entrepreneurial networking and develop scales that will explicitly differentiate them, and also enable researchers to collect data on them.

\section{Conclusion}

The purpose of this study was to investigate the influence of different forms of networking on business performance of SMEs. The findings of this study revealed a significant relationship between network maintenance and performance of SMEs. Accordingly, business networks influence business performance, and these networks are not differentiated whether social, business or managerial. The findings support the argument that relationships with direct partners will increase access to information because partners are more willing and able to share information. These business networks will enable an enterprise to gain more clients, shareholders, business associates' suppliers and technical and market knowledge (Möller 2013).

This study indicates that entrepreneurs are participative in networks and actively build and maintain them. However, they seem to overvalue or exaggerate its importance which is a risk as it negatively affects the performance of the business. Future studies can consider mixed-method approach to investigate further why there is a negative relationship between the perceived importance of networking and SME performance and as to what point networking can be categorised as over-networking. This approach will allow researchers to get richer insights into the negative relationships.

Furthermore, the study revealed that having and maintaining networks influence SME performance. The change in business performance can be explained by networking that the entrepreneur maintains.

Surprisingly, the study findings suggested that the more the entrepreneur thinks networking is important, the lower the level of business performance, which seems to 
contradict the fact that the more the entrepreneur networks, the higher the performance of the business. Therefore, this study recommends that more research should be conducted to investigate what seems like a contradiction between the importance and maintenance of networks in relation to thebusiness performance of SMEs. These findings may contribute to the current literature that has so far produced inconclusive findings by showing that more differentiation on the forms of networking is needed before further research can be conducted so that reliable scales are used and valid data are subsequently collected.

\section{Acknowledgements Competing interests}

The authors have declared that no competing interests exist.

\section{Authors' contributions}

S.H.M. conceptualised the study that was part of her master's thesis and J.M.-G. was the supervisor who assisted with the conceptualisation and development of the article and primarily the data analysis section.

\section{Funding information}

This research received no specific grant from any funding agency in the public, commercial or not-for-profit sectors.

\section{Data availability statement}

Data sharing is not applicable to this article as no new data were created or analysed in this study.

\section{Disclaimer}

The views and opinions expressed in this article are those of authors and do not necessarily reflect the official policy or position of any affiliated agency of the authors.

\section{References}

Adler, P.S. \& Kwon, S.-W., 2002, 'Social capital: Prospects for a new concept', Academy of Management Review 27(1), 17-40. https://doi.org/10.5465/amr.2002.5922314

Anwar, M. \& Ali Shah, S.Z., 2018, 'Managerial networking and business model innovation: Empirical study of new ventures in an emerging economy', Journal of Small Business \& Entrepreneurship, 1-22. https://doi.org/10.1080/08276331.201 8.1490509

Anwar, M., Rehman, A.U. \& Shah, S.Z.A., 2018, 'Networking and new venture's performance: Mediating role of competitive advantage', International Journal of
Emerging Markets 13(5), 998-1025. https://doi.org/10.1108/IJoEM-07-2017-0263

Aremu, M.A. \& Adeyemi, S.L., 2011, 'Small and medium scale enterprises as a survival strategy for employment generation in Nigeria', Journal of Sustainable Development 4(1), 200. https://doi.org/10.5539/jsd.v4n1p200

Baum, J.R., Locke, E.A. \& Smith, K.G., 2001, 'A multidimensional model of venture growth', Academy of Management Journal 44(2), 292-303. https://doi.org/ 10.5465/3069456

Besser, T.L., Miller, N. \& Perkins, R.K., 2006, 'For the greater good: Business networks and business social responsibility to communities', Entrepreneurship and Regiona
Development 18(4), 321-339. https://doi.org/10.1080/08985620600715046

Burt, R.S., 2009, Structural holes: The social structure of competition, Harvard University Press, Cambridge, MA.

Chen, C.-N., Tzeng, L.-C., Ou, W.-M. \& Chang, K.-T., 2007, 'The relationship among social capital, entrepreneurial orientation, organizational resources and entrepreneurial performance for new ventures', Contemporary Management Research 3(3), 213-232. https://doi.org/10.7903/cmr.90

Chen, Y. \& He, Y., 2011, 'The impact of strong ties on entrepreneurial intention: An empirical study based on the mediating role of self-efficacy', Journal of Chinese Entrepreneurship 3(2), 147-158. https://doi.org/10.1108/17561391111144573
Chittithaworn, C., Islam, M.A., Keawchana, T. \& Yusuf, D.H.M., 2011, 'Factors affecting business success of small \& medium enterprises (SMEs) in Thailand', Asian Socia Science 7(5), 180-190. https://doi.org/10.5539/ass.v7n5p180

Chung, H.F., 2012, 'Export market orientation, managerial ties, and performance', International Marketing Review 29(4), 403-423. https://doi.org/10.1108/0265 1331211242638

Coff, R.W., 1999, 'When competitive advantage doesn't lead to performance: The resource-based view and stakeholder bargaining power', Organization Science 10(2), 119-133.

Coleman, J.S. \& Coleman, J.S., 1994, Foundations of Social Theory, Harvard University Press, Cambridge, MA.

Cook, P. \& Uchida, Y., 2004, 'Performance of privatised regulated and non-regulated enterprises in developing countries', paper presented at the third CRC interprises in developing countries', paper presented at the third CRC international conference on pro-poor regulation and competition: issues, policies
and practices, University of Stellenbosch, BMW Pavilion, Cape Town, South Africa.

Cooney, T.M. \& Flynn, A., 2008, A mapping of ethnic entrepreneurship in Ireland, Minority Entrepreneurship, Technolgoical University Dublin.

Cooper, D. \& Schindler, P., 2014, Business research methods. McGraw-Hill, New York.

Cooper, L. \& Nakanishi, M., 2010, Evaluating competitive marketing effectiveness: Market-share analysis. Kluwer Academic Publishers, Boston, MA.

Coulibaly, S.K., Erbao, C. \& Mekongcho, T.M., 2018, 'Economic globalization, entrepreneurship, and development', Technological Forecasting and Socia Change 127, 271-280. https://doi.org/10.1016/j.techfore.2017.09.028

Coulthard, M. \& Loos, J., 2007, 'Networking, the missing link in firm based entrepreneurial orientation (Eo) performance models', Monash University Business and Economics Working Paper, 1-13.

Creswell, J.W., 2014, Research design: Qualitative, quantitative, and mixed methods approaches, Sage, Los Angeles, CA.

Davidsson, P. \& Honig, B., 2003, 'The role of social and human capital among nascent entrepreneurs', Journal of Business Venturing 18(3), 301-331. https://doi. org/10.1016/S0883-9026(02)00097-6

Delmar, F., Davidsson, P. \& Gartner, W.B., 2003, 'Arriving at the high-growth firm', Journal of Business Venturing 18(2), 189-216. https://doi.org/10.1016/ S0883-9026(02)00080-0

Drost, E.A., 2011, 'Validity and reliability in social science research', Education Research and Perspectives 38(1), 105

Fatoki, O.O., 2011, 'The impact of human, social and financial capital on the performance of small and medium-sized enterprises (SMEs) in South Africa', Journal of Social Sciences 29(3), 193-204. https://doi.org/10.1080/09718923.201 Journal of Socic

Field, A., 2013, Discovering statistics using IBM SPSS statistics, 4th edn., Sage, Los Angeles, CA.

Field, A., 2016, Discovering statistics using IBM SPSS statistics, 5th edn., Sussex University, Sage, Los Angeles, CA.

Ford, D. \& Mouzas, S., 2013, 'The theory and practice of business networking', Industrial Marketing Management 42(3), 433-442. https://doi.org/10.1016/j. indmarman.2013.02.012

Franco, M., 2018, 'Networking as a marketing tool in small companies: A random and informal approach', Journal of Business Strategy 39(2), 47-55. https://doi. org/10.1108/JBS-02-2017-0020

Galawe, N.J., 2017, 'Endogenous and exogenous risk factors in the success of South African small medium enterprises' PhD thesis, University of the Witwatersrand, Johannesburg.

Garwe, D.K. \& Fatoki, O., 2012, 'The impact of gender on SME characteristics and access to debt finance in South Africa', Development Southern Africa 29(3), 448-461. https://doi.org/10.1080/0376835X.2012.706040

Gedajlovic, E., Honig, B., Moore, C.B., Payne, G.T. \& Wright, M., 2013, Social capital and entrepreneurship: A schema and research agenda, Sage, Los Angeles, CA https://doi.org/10.1111/etap.12042

Gold, S.J. \& Light, I., 2000, Ethnic economies and social policy, research in social movements, conflicts and change. Emerald Group Publishing Limited, Bingley, UK.

Grobbelaar, S.S., Gwynne-Evans, N. \& Brent, A.C., 2016, 'From enterprise development to inclusive innovation-A systemic instruments framework for regional innovation support', African Journal of Science, Technology, Innovation and Development 8(2), 233-246. https://doi.org/10.1080/20421338.2016.1159401

Hair, J.F., Black, W.C., Babin, B.J. \& Anderson, R.E., 2010, Multivariate data analysis: A global perspective 7 edn., Pearson, Hoboken, NJ.

Håkansson, H. \& Snehota, I., 2017, No business is an island: Making sense of the interactive business World, Emerald Publishing Limited, Bingley, UK. https://doi. org/10.1108/9781787145498

Håkansson, H. \& Snehota, I., (eds.), No Business is an Island, Emerald Publishing Limited, pp. i-xii. https://doi.org/10.1108/978-1-78714-549-820171016

Hassan, N.A., Abdullah, A., Noor, M.M., Din, H.A.M., Abdullah, N.H. \& Ismail, M.M., 2018, 'Business networking and social cohesion among business community in Malaysia', International Journal of Asian Social Science 8(9), 669-676. https://doi. org/10.18488/journal.1.2018.88.669.676

Hazzard-Robinson, D.D., 2012, 'Social network theory in inter-organizational alliances: An exploratory examination of mobile payments engagement', $\mathrm{PhD}$ dissertation, Georgia State University, Atlanta, GA.

Herrington, M., Kew, P. \& Mwanga, A., 2017, 'South Africa: Can small businesses survive in South Africa?', Gem South Africa Report 2016/2017, University of Cape Town, Cape Town, viewed August 2018, from https://www.gemconsortium.org/ report/49833. 
Heshmati, N., 2013, The impact of networking on access to bank finance for SMEs: Comparison of Iran and Sweden, Independent thesis Advanced Level, Halmastad University, School of Business and engineering, Halmstad.

Hubert, O., Elgar, F. \& Rainer, A., 2001, Business networking: Shaping collaboration between enterprises, Sage, London.

Huggins, R., 2018, The business of networks: Inter-firm interaction, institutional policy and the Tec experiment, 1st edn., Routledge, London. https://doi. org/10.4324/9781315197210

Hung, H., 2006, 'Formation and survival of new ventures: A path from interpersonal to interorganizational networks', International Small Business Journal 24(4), 359-378. https://doi.org/10.1177/0266242606065508

Jack, S., Dodd, S.D. \& Anderson, A.R., 2008, 'Change and the development of entrepreneurial networks over time: A processual perspective', Entrepreneurship and Regional Development 20(2),125-159. https://doi.org/10.1080/08985620701645027

Johnson, G., Scholes, K. \& Whittington, R., 2005, Exploring corporate strategy: Text \& cases 2008, ARTMED, Porto Alegre.

Jones, C., Hesterly, W.S. \& Borgatti, S.P., 1997, 'A general theory of network governance: Exchange conditions and social mechanisms', Academy of Management Review 22(4), 911-945. https://doi.org/10.5465/amr.1997.9711022109

Kellen, V. \& Wolf, B., 2003, 'Business performance measurement', Information Visualization 1(312), 1-36.

Krebs, V., 2008, 'Social capital: The key to success for the 21st century organization', IHRIM Journal 12(5), 38-42.

Kumar Panda, D., 2014, 'Managerial network impacts firm performance', Performance Improvement Quarterly 27(1), 5-32. https://doi.org/10.1002/piq.21164

Kwon, S.-W. \& Arenius, P., 2010, 'Nations of entrepreneurs: A social capital perspective', Journal of Business Venturing 25(3), 315-330. https://doi.org/10.1016/j. jbusvent.2008.10.008

Labianca, G. \& Brass, D.J., 2006, 'Exploring the social ledger: Negative relationships and negative asymmetry in social networks in organizations', Academy of Management Review 31(3), 596-614. https://doi.org/10.5465/amr.2006.21318920

Le, N.T. \& Nguyen, T.V., 2009, 'The impact of networking on bank financing: The case of small and medium-sized enterprises in Vietnam', Entrepreneurship Theory and Practice 33(4), 867-887. https://doi.org/10.1111/j.1540-6520. 2009.00330.

Lea, B.-R., Yu, W.-B., Maguluru, N. \& Nichols, M., 2006, 'Enhancing business networks using social network based virtual communities', Industrial Management \& Data Systems 106(1), 121-138. https://doi.org/10.1108/02635570610641022

Leech, N.L., Barrett, K.C. \& Morgan, G.A., 2014, IBM SPSS for intermediate statistics: Use and interpretation, 5th edn., Routledge, New York, NY. https://doi. org/10.4324/9780203122778

Li, D. \& Ferreira, M.P., 2006, 'The evolutionary model of entrepreneurial firms' dependence on networks: Going beyond the start-up page', Notas Económicas (24), 48-63.

Li, H. \& Zhang, Y., 2007, 'The role of managers' political networking and functional experience in new venture performance: Evidence from China's transition economy', Strategic Management Journal 28(8), 791-804. https://doi. org/10.1002/smj.605

Li, J.J., 2005, 'The formation of managerial networks of foreign firms in China: The effects of strategic orientations', Asia Pacific Journal of Management 22(4), 423-443. https://doi.org/10.1007/s10490-005-4118-8

Love, J.H. \& Roper, S., 2015, 'SME innovation, exporting and growth: A review of existing evidence', International Small Business Journal 33(1), 28-48. https://doi. org/10.1177/0266242614550190

Low, M.B. \& MacMillan, I.C., 1988, 'Entrepreneurship: Past research and future challenges', Journal of Management 14(2), 139-161. https://doi.org/10.1177/01 4920638801400202

Luo, Y., 2003, 'Industrial dynamics and managerial networking in an emerging market: The case of China', Strategic Management Journal 24(13), 1315-1327. https:// doi.org/10.1002/smj.363

Machirori, T. \& Fatoki, O., 2013, 'The impact of firm and entrepreneur's characteristics on networking by SMEs in South Africa', Journal of Economics 4(2), 113-120. https://doi.org/10.1080/09765239.2013.11884971

Marimuthu, M., Arokiasamy, L. \& Ismail, M., 2009,' Human capital development and its impact on firm performance: Evidence from developmental economics', Journal of International Social Research 2(8), 2

McFarlin, D.B., Coster, E.A. \& Mogale-Pretorius, C., 1999, 'South African management development in the twenty-first century: Moving toward an Africanized model' Journal of Management Development 18(1), 63-78. https://doi.org/10.1108/ 02621719910250474

Miller, C.C., Washburn, N.T. \& Glick, W.H., 2013, 'Perspective-The myth of firm performance', Organization Science 24(3), 948-964. https://doi.org/10.1287/ orsc.1120.0762

Möller, K., 2010, 'Relationships and networks', in M.J. Baker \& M. Saren (eds.), Marketing theory: A student text, pp. 304-329, Sage, London. https://doi. org/10.4135/9781446280096.n14

Möller, K., 2013, 'Theory map of business marketing: Relationships and networks perspectives', Industrial Marketing Management 42(3), 324-335. https://doi. org/10.1016/j.indmarman.2013.02.009

Msimango-Galawe, J. \& Urban, B., 2019, 'An integrated approach to SME risk assessment: A focus on endogenous and exogenous risk factors', African Review of Economics and Finance 11(1), 142-177.
Munyanyi, W. \& Pooe, D., 2019, 'The influence of absorptive capacity and networking capabilities on small and medium enterprises', Southern African Journal of Entrepreneurship and Small Business Management 11(1), a231. https://doi. Entrepreneurship and Small Busi
org/10.4102/sajesbm.v11i1.231

Obeng, B.A., Robson, P. \& Haugh, H., 2014, 'Strategic entrepreneurship and small firm growth in Ghana', International Small Business Journal 32(5), 501-524. https:// doi.org/10.1177/0266242612463946

Olawale, F. \& Garwe, D., 2010, 'Obstacles to the growth of new SMEs in South Africa: A principal component analysis approach', African Journal of Business Management 4(5), 729-738.

O'Toole, T. \& McGrath, H., 2018, 'Strategic patterns in the development of network capability in new ventures', Industrial Marketing Management 70, 128-140. https://doi.org/10.1016/j.indmarman.2017.07.003

Peng, M.W. \& Luo, Y., 2000, 'Managerial ties and firm performance in a transition economy: The nature of a micro-macro link', Academy of management journa 43(3), 486-501.

Petersen, M.A. \& Schoeman, I., 2008, 'Modeling of banking profit via return-on-assets and return-on-equity', Proceedings of the World Congress on Engineering, 2008, pp. 1-6.

Porter, M.E., 1989, 'How competitive forces shape strategy', in D. Asch \& C. Bowman (eds.), Readings in strategic management, Palgrave, London. https://doi. (eds.), Readings in strategic man
org/10.1007/978-1-349-20317-8_10

Portes, A., 1998, 'Social capital: Its origins and applications in modern sociology', Annual Review of Sociology 24(1), 1-24. https://doi.org/10.1146/annurev.soc.24.1.1

Pratono, A.H., 2018, 'From social network to firm performance: The mediating effect of trust, selling capability and pricing capability', Management Research Review 41(6), 680-700. https://doi.org/10.1108/MRR-03-2017-0080

Rosenbusch, N., Brinckmann, J. \& Müller, V., 2013, 'Does acquiring venture capital pay off for the funded firms? A meta-analysis on the relationship between venture capital investment and funded firm financial performance', Journal of Business Venturing 28(3), 335-353. https://doi.org/10.1016/j.jbusvent.2012.04.002

Rowley, T., Behrens, D. \& Krackhardt, D., 2000, 'Redundant governance structures: An analysis of structural and relational embeddedness in the steel and semiconductor industries', Strategic Management Journal 21(3), 369-386. https://doi. org/10.1002/(SICI)1097-0266(200003)21:3\%3C369::AID-SMJ93\%3E3.0.CO;2-M

Sarens, G., Everaert, P., Verplancke, F. \& De Beelde, I., 2015, 'Diversification of external accountants serving small and medium-sized enterprises: Evidence from Belgium', Australian Accounting Review 25(2), 155-174. https://doi.org/10.1111/auar.12078

Schayek, R. \& Dvir, D., 2011, 'The Impact of Public Assistance Programs on Smal Businesses: Strategic Planning, Entrepreneurship Resources Usage, and Market Orientation as Mediating Variables', Journal of Small Business Strategy 22(1), 67-98.

Schoonjans, B., Van Cauwenberge, P. \& Vander Bauwhede, H., 2013, 'Formal business networking and SME growth', Small Business Economics 41(1), 169-181. https:// doi.org/10.1007/s11187-011-9408-6

Seed Academy, 2017, The real state of entrepreneurship survey, Seed Engine, Johannesburg

Selvarajan, T., Ramamoorthy, N., Flood, P.C., Guthrie, J.P., MacCurtain, S. \& Liu, W. 2007 , 'The role of human capital philosophy in promoting firm innovativeness and performance: Test of a causal model', The International Journal of Human Resource Management 18(8), 1456-1470. https://doi.org/10.1080/09585190701502588

Shava, H. \& Rungani, E.C., 2016, 'Influence of gender on SME performance in emerging economies', Acta Commercii 16(1), 1-9. https://doi.org/10.4102/ac.v16i1.408

Simsek, Z. \& Heavey, C., 2011, 'The mediating role of knowledge-based capital for corporate entrepreneurship effects on performance: A study of small- to mediumsized firms', Strategic Entrepreneurship Journal 5(1), 81-100. https://doi. org $/ 10.1002 /$ sej.108

Smit, Y. \& Watkins, J.A., 2012, 'A literature review of small and medium enterprises (SME) risk management practices in South Africa', African Journal of Business Management 6(21), 6324-6330. https://doi.org/10.5897/AJBM11.2709

Steier, L. \& Greenwood, R., 2000, 'Entrepreneurship and the evolution of Angel financial networks', Organization Studies 21(1), 163-192. https://doi.org/10.11 77/0170840600211002

Steigenberger, N., 2014, 'Only a matter of chance? How firm performance measurement impacts study results', European Management Journal 32(1), 46-65. https://doi.org/10.1016/j.emj.2013.09.003

Su, Z., Xie, E., Wang, D. \& Li, Y., 2011, 'Entrepreneurial strategy making, resources, and firm performance: Evidence from China', Small Business Economics 36(2), 235-247. https://doi.org/10.1007/s11187-009-9211-9

Taylor, M. \& Murphy, A., 2004, 'SMEs and e-business', Journal of Small Business and Enterprise Development 11(3), 280-289. https://doi.org/10.1108/1462 6000410551546

Tendai, C., 2013, 'Networks and performance of small and medium enterprises (SMEs) in different stages of the life cycle: A case study of a small business in the Netherlands', Journal of Communication 4(2), 89-94. https://doi.org/10.1080/09 76691X.2013.11884811

Thrikawala, S., 2011, 'Impact of strategic networks for the success of SMEs in Sri Lanka', World Journal of Social Sciences 1(2), 108-119.

Urban, B. \& Sefalafala, M.R., 2015, 'The influence of entrepreneurial intensity and capabilities on internationalisation and firm performance', South African Journal of Economic and Management Sciences 18(2), 260-276. https://doi.org/10.4102/ sajems.v18i2.841

Valkokari, K. \& Helander, N., 2007, 'Knowledge management in different types of strategic SME networks', Management Research News 30(8), 597-608. https:// doi.org/10.1108/01409170710773724 
Venter, R., Urban, B., Beder, L., Oosthuizen, C., Reddy, C. \& Venter, E., 2015, Entrepreneurship: Theory in practice, Oxford University Press, Cape Town.

Wang, M.-C., Chen, P.-C. \& Fang, S.-C., 2018, 'A critical view of knowledge networks and innovation performance: The mediation role of firms' knowledge integration capability', Journal of Business Research 88, 222-233. https://doi.org/10.1016/j. jbusres.2018.03.034

Wasserman, S. \& Faust, K., 1994, Social network analysis: Methods and applications, Cambridge University Press. https://doi.org/10.1017/CBO9780511815478

Watson, J., 2007, 'Modeling the relationship between networking and firm performance', Journal of Business Venturing 22(6), 852-874. https://doi.org/10.1016/j.jbusvent. 2006.08.001
Watson, J., 2012, 'Networking: Gender differences and the association with firm performance', International Small Business Journal 30(5), 536-558. https://doi. org/10.1177/0266242610384888

West, G.P. \& Noel, T.W., 2009, 'A multidimensional model of venture growth' Journal of Small Business Management 47(1), 1-22. https://doi.org/10.1111/ j.1540-627X.2008.00259.x

Wiklund, J. \& Shepherd, D., 2005, 'Entrepreneurial orientation and small business performance: A configurational approach', Journal of Business Venturing 20(1), 71-91. https://doi.org/10.1016/j.jbusvent.2004.01.001

Xu, Z., Lin, J. \& Lin, D., 2008, 'Networking and innovation in SMEs: Evidence from Guangdong province, China', Journal of Small Business and Enterprise Development 15(4), 788-801. https://doi.org/10.1108/14626000810917861 